\title{
Thinking Locally, Acting Globally
}

Just over twenty-five years ago, in Brussels, a huge gathering of politicians, diplomats, Jewish leaders, civil society, intellectuals, academics and activists, convened to celebrate a new era-after the fall of the Soviet Union-in which antisemitism had been relegated to the gutters from which it had emerged.

At "My Brother's Keeper: World Conference on Anti-Semitism and Prejudice in a Changing World," the optimism was all but pervasive. A number of keynote speakers and assorted experts exuded a faith in both the present and future. The handful of dissenters-of which I was one-were relegated to the sidelines for suggesting it was too early to know what we were witnessing, let alone what the future may have held.

The serious activists amongst that assembly-and from the multitudes not included in it-have generally concentrated efforts not just on documenting antisemitism but taking initiatives to maximise the chances that antisemitism would, at the very least, be socially unacceptable and that it would serve to impede the political progress of any who espoused it.

This may explain why these deliberations are taking place at a time when, wherever one turns, one sees what I will call "non-antisemitism"-where any actor rejects the label of being antisemitic, despite objective evidence.

In the United Kingdom, many loud, occasionally dissonant, voices articulate the view that the "non-antisemitism" in the British Labour Party should be promoted as an innate left-wing value, ${ }^{2}$ proclaimed from the rooftops of Labour boroughs, as this is part of the Momentum ${ }^{3}$ toward inevitable rebuilding of that venerable democracy.

In Norway, Bjørnar Moxnes a member of Parliament who previously had an international profile just a little below that of a Scottish third division football team, has been proclaiming the "non-antisemitism" of his move to have the bul-

1 Cf. World Jewish Congress, ed., My Brother's Keeper: World Conference on Anti-Semitism and Prejudice in a Changing World, July 6-8, 1992, Brussels, Belgium (Brussels: World Jewish Congress, 1992).

2 See D. Rich, The Left's Jewish Problem (London: Biteback, 2018), and D. Hirsh, Contemporary Left Antisemitism (London: Routledge, 2018).

3 Momentum is a mass membership organisation in the British Labour movement. For its relevance to this discussion, see R. Marchant, "We Need to Talk about Momentum and anti-Semitism,” Labour Uncut, issued January 17, 2018, accessed March 23, 2020, http://labour-uncut. co.uk/2018/01/17/we-need-to-talk-about-momentum-and-anti-semitism/.

Ә OpenAccess. (C) 2021 Armin Lange, Kerstin Mayerhofer, Dina Porat, Lawrence H. Schiffmann, published by De Gruyter. (cc) BY-NC-ND This work is licensed under the Creative Commons Attribution-NonCommercialNoDerivatives 4.0 International License. https://doi.org/10.1515/9783110671964-021 
lies, defamers, and slanderers, the so-called BDS movement, receive a Nobel Prize. ${ }^{4}$ He was reported to have said his political stance was "completely free of antisemitism." 5

The intense "non-antisemitism" in discussions of one individual, in an episode perhaps best labelled the Tsures ${ }^{6}$ of Soros, has been reaching fever-pitch in recent weeks. ${ }^{7}$

Organisations such as Sunni-badged Hamas and the-clearly-in-no-way-related Shi'a imperialists of Iran, ${ }^{8}$ are keen to promote their "non-antisemitism" to the West, often recruiting the virtually talentless street performers from the miniscule and theologically deviant Jewish sect, Neturei Karta, ${ }^{9}$ to act as the chorus to the Islamist virtuosi.

Is it ungenerous to not welcome the prevalence of this "non-antisemitism?" After all, it is partial acknowledgement of quite a dramatic change in the state of public discourse, at least for much of the West and those parts of the planet upon which European philosophies have had the greatest impact. It may be that we live in an unusual time.

How often, in how many places, in all of recorded history, would attitudes toward members of an out-group be cause for great reflection, much less potential embarrassment? In the religious sphere, treating others with contempt, vilifying those who refused to acknowledge any variety of the One True Way, endowing characteristics upon them which furthered one's own claim to moral superiority and contributing to their misery, thus providing further testimony to one's own righteousness, be anything others than Articles of Faith? Judaism, and its both subjectively and objectively confusing adherents, has been a reli-

4 Cf. "Norwegian MP Defends Nominating 'Peaceful' BDS Movement for Nobel Prize,” The Times of Israel, February 11, 2017, https://www.timesofisrael.com/norwegian-mp-defends-nomi nating-peaceful-bds-movement-for-nobel-prize/.

5 Ibid. For a good discussion on the relationship of BDS to antisemitism, see K. L. Marcus, "Is the Boycott, Divestment, and Sanctions Movement Anti-Semitic?," in The Case Against Academic Boycotts of Israel, ed. C. Nelson and G. N. Braham (Chicago: Wayne State University Press, 2015), $243-58$.

6 "Tsuros" is the Yiddish/Ashkenazi rendering of the Hebrew word meaning "troubles."

7 For background see E. D. Guerrero and A. Schonberger, "The Nationalist Hungarian Government is Endangering Jewish People with its Smear Campaign against Philanthropist George Sorors," The Independent, December 3, 2017, https://www.independent.co.uk/voices/hungary-gov ernment-george-soros-viktor-orban-antisemitism-a8089621.html.

8 Cf. C. B. Glick, “Column One: Hamas and the Nexus of Global Jihad,” The Jerusalem Post, February 5, 2015, https://www.jpost.com/Opinion/Hamas-and-the-nexus-of-global-jihad-390182.

9 See D. Sugarman, "A Short Guide to Neturei Karta, the anti-Zionist's Favourite Fringe Jewish Sect,” The Jewish Chronicle (UK), September 11, 2017, https://www.thejc.com/comment/com ment/who-are-the-neturei-karta-1.444090. 
gion which has coexisted with numerically superior, passively or not-so-passively aggressively others, for millennia. Literature testifying to feelings of embarrassment by those in the intellectual leadership of movements declaring Judaism and Jews as deserving of contempt, maltreatment, and even hatred is far more difficult to locate than are rationalisations for this behaviour.

Christianity included Jewish religious texts in its Holy Canon, reliant on some of these for the very essence of its own narrative of Divine Intervention in the affairs of humanity. It developed as a rival to Judaism. The Gospel was first shared with Jews. Early Christians and Jews shared communities, and from the very beginning, there was an issue of the attitude of Believers in a Revealed Truth meant for all humanity toward those who knew and could have accepted the Way but refused to do so. In the essential principles of each, only one interpretation could be correct. Further, it mattered very much to Christians that this was the case. Add to this admixture the accusation of Deicide, and you have some powerful motivators at work. For most of the past two millennia, anti-Judaism was de rigueur, not a cause of discomfiture or something of which to be embarrassed or ashamed. That is not to suggest for a moment that the translation of this attitude into persecution, mistreatment, and murder was never an issue for devout Christians-only that Jews and Judaism were particularly confronting. ${ }^{10}$

One should not underestimate the cathartic impact of the Shoah, particularly given the cultural Christianity of the societies from which Nazism and its supporters emerged and the overlap between religious preaching of hatred and the acceptance of "racial" antisemitism. It is barely half a century since the overhaul of Catholic teaching at the Second Vatican Council, ${ }^{11}$ a little over thirty years since the first Papal descriptions of antisemitism first as deplorable ${ }^{12}$ and then as a $\sin ,{ }^{13}$ with most Protestant theologising and Eastern reflection on the subject of the nexus between a self-defined religion of love and the consequences of human interpretation of a Divine moral code even more recent.

10 W. Nicholls, Christian Antisemitism: A History of Hate (London: Jason Aronson, 1993) presents a good overview.

11 Cf. Pope Paul VI, Nostra Aetate: Declaration On The Relation Of The Church To Non-Christian Religions, issued October 28, 1965, accessed July 17, 2018, http://www.vatican.va/archive/hist_ councils/ii_vatican_council/documents/vat-Ii_decl_19651028_nostra-aetate_en.html.

12 Cf. Pope John Paul II, “To the Jewish Community of Rome," speech at Rome Synagogue, issued April 13, 1986, accessed March 30, 2020, http://www.vatican.va/content/john-paul-ii/de/ speeches/1986/april/documents/hf_jp-ii_spe_19860413_sinagoga-roma.html. [German]

13 Cf. Pope John Paul II, “To the Representatives of the Jewish Community in Sydney," speech, issued November 26, 1986, accessed March 30, 2020, http://www.vatican.va/content/john-paulii/en/speeches/1986/november/documents/hf_jp-ii_spe_19861126_com-ebraica-sidney-austral ia.html. 
The position of another great World Religion, Islam, is in a sense more nuanced with its antagonisms toward Judaism and Jews taking different forms which have often lacked the Manichean overlay of Christian conceptions. As is the case with Christianity, there are direct references to Jews and Judaism in Holy Teachings. The Faith developed in the presence of and proximity to Jewish believers who had the opportunity to accept The Truth. The Qur'an includes significant references to personalities and episodes familiar to Jews, and commentary is included which makes (generally negative) references to Jews, leaving it open to interpretation as to what these references mean. Additionally, there are hadiths, testaments of the words and actions of the Messenger, by various contributors and in a number of compilations, which have been used to form attitudes toward Jews and Judaism.

It is not difficult to find emphasis on passages which paint Judaism as it is practised, the behaviour of specific Jews or Jews as a group in a negative light in the Islamic world, just as it is not difficult to find emphases on Judaism as Monotheism (in a superior class to Christianity) and on passages promoting goodwill. It is as disingenuous to deny that there are not significant numbers of Muslims who say in prayers-for many seventeen times a day-that they seek guidance to avoid becoming like the Jews, ${ }^{14}$ or that apocalyptic visions of a war with Jewish enmity to Islam defeated are not very common, as it would be to deny the streams which both promoted and practiced a far gentler attitude to the religion and its followers. But it must be noted that those who held even the most negative of views or carried out the worst excesses of discrimination and persecution would not have felt any need to proclaim that they were not true believers in the morality and theological buttresses of their activities.

The above references to religion were selected to remove doubt that discomfort or embarrassment, let alone regret, were not hallmarks of the presentation of the Oldest Hatred even from movements which include such concepts in their essences.

It should be self-evident that those who define Jews as racial, let alone religious, existential enemies of all which is good, would not pretend that they were embarrassed to be anti-Jewish. Indeed, one can gain wry amusement in observing how the different strains of racist antisemitism compete to prove which of

14 Cf. S. A. Aldeeb Abu-Sahlieh, The Fatiha and the Culture of Hate: Interpretation of the 7th Verse through the Centuries (Scotts Valley: Create Space, 2015); "Egyptian Writers Criticize The Negative Attitude to Christians and Jews Reflected in The Common Interpretation of the Fatiha," MEMRI, Special Dispatch No.7025, issued July 25, 2017, accessed March 23, 2020, https://www. memri.org/reports/egyptian-writers-criticize-negative-attitude-christians-and-jews-reflected-com mon. 
them hates Jews more, and which has better strategies in intimidating, upsetting, offending, and hurting Jews individually and collectively. In one relatively recent example, we had well-known English reputation self-immolator and a-historian David Irving chastise open denier of the Holocaust, Fredrick Töben, for having an "antisemitic website" which gave misrepresentation of historical truth a bad name. ${ }^{15}$

For a variety of historic factors, not least of which was intellectually opportunistic anti-colonialism and another the weakening of institutions of liberal democracies, proclaiming anti-racism (including "non-antisemitism") has become an essential part of rhetoric from significant segments of contemporary selfdefined left-wing movements. No matter how self-evident left-wing racism (and I am not only referring to antisemitism) may be, these selectively progressives will argue, until they are green in the face, that they cannot possibly be racist because they are of the left.

Remember Durban, 2001, the UN World Conference Against Racism and the accompanying Youth and NGO Fora? My personal memories include not just leaflets bemoaning Hitler's failure to kill every Jew on the planet or cartoon booklets containing images of Jews as hook-nosed, clawed, blood-dripping-from-teeth subhumans or the sale of obscene antisemitic texts on sovereign UN soil, but the way so much of the human rights world accepted this as a legitimate (if slightly unsavoury) part of a legitimate political struggle. ${ }^{16}$ The other memory that came from that period was the way an email address I established specifically for that conference suddenly received steady traffic a few days after I returned home-and just after the September 11th terrorist attacks in New York. These emails stated variously that the terrorist attacks were good things, the terrorist attacks never happened, or that Jews were responsible for so-called "false flag" attacks.

I was at the UN Conference in Durban as a delegate appointed by the Government of Australia and at the NGO Conference representing the World Jewish Congress. It was my privilege to present at a session organised by the Jewish caucus against antisemitism and to take part in the activities of the Australian NGO Caucus and with colleagues in the Indigenous caucus. I spoke on the manifestations of antisemitism as the new millennium was beginning, in what is arguably

15 Cf. D. Irving, “Action Report,” issued July 20, 2000.

16 Cf. J. Jones, "Durban Daze: When Anti-Semitism becomes Anti-Racism,” Australia/Israel Review, October 26, 2001. 
the world's most Jewish-friendly country, Australia, and how we were dealing with it. $^{17}$

First, we had engaged in widespread education. We tried to help all Australians see opposition to antisemitism as one of, or at least consistent with, what it meant to be a good Australian. ${ }^{18}$ This was particularly significant given that Australia is a country of immigration, with high proportions of the population born outside Australia and even higher proportions having one or more parents born overseas. It is significant that we saw antisemitic parents not passing on hatred to the next generation-because the next generation wanted to be "Australian."19

Understanding that this task required more hands than the maximum of two each from every Jew, we had been building alliances, coalitions, partnerships, and cooperative ventures. ${ }^{20}$ Our national protestant Uniting Church had taken aboard the need for Christians to not only purge their souls from antisemitism but to help purge the national soul of the same evil. ${ }^{21}$

We had used the law to the extent that editors, internet service providers, employers, political parties, religious institutions, and civil society understood that antisemitism could have consequences (beyond hurt to the targets/victims). Arabic papers in the Middle East may publish antisemitic pseudo-analyses of world affairs-but Australian Arabic newspapers could not reprint them. ${ }^{22}$ Holocaust denial on the internet, if posted by an Australian resident or hosted by an Australian server, could have courts order its removal. ${ }^{23}$ Years of leafletting anti-

17 Cf. J. Jones, “Confronting Reality: Anti-Semitism in Australia Today,” Jewish Political Studies Review 16, nos. 3-4 (2004), https://www.jcpa.org/phas/phas-jones-f04.htm.

18 Cf. S. Rutland, "Negotiating Religious Dialogue: A Response to the Recent Increase in antiSemitism in Australia," in Negotiating the Sacred: Blasphemy and Sacrilege in a Multicultural Society, ed. E. Burns Coleman and K. White (Canberra: ANU Press, 2006), 17-30.

19 Cf. M. F. Haverluck, “Muslim Refugees' Archaic Views of Jews, Women, Infidels," One News Now, January 23, 2018, https://onenewsnow.com/culture/2018/01/23/muslim-refugees-archaicviews-of-jews-women-infidels.

20 Cf. J. Jones, “The Jewish Community of Australia and Its Challenges," Jerusalem Center for Public Affairs 13 (2006), https://jcpa.org/article/the-jewish-community-of-australia-and-its-chal lenges/.

21 See the Reports on the activities of the Uniting Church in Australia/Jewish Community National Dialogue (1991 to present), the Annual Conversation of the Jewish Community at the Australian Catholic Bishops' Conference (1998 to present), the Australian National Dialogue of Christians, Muslims \& Jews (2002 to present) and other national, regional, and informal dialogues can be found in the Annual Reports of The Executive Council of Australian Jewry (1992 to 2018).

22 Cf. J. Jones, “Erasing Hatred,” Australia/Israel Review, July 25, 1997.

23 Cf. Toben vs. Jones [2003] FCAFC 137 (Judgement of full bench of the Federal Court of Australia). 
Jewish slanders could be ended with one complaint, as laws developed. ${ }^{24}$ (Later cases demonstrated that protected political speech did not include promotion of antisemitism in a party's paper and that freedom of religion did not include freedom to promote hatred of others). ${ }^{25}$

We had, with a large degree of success, developed local responses to global phenomena and, to some measure, expanded the understanding of the destructive nature of antisemitism beyond national borders. Jewish leaders of the generation of my parents could proudly speak of the way the Australian Lutheran Church, for example, had led other Lutherans in thinking of Judaism as a living faith and not something superceded millennia ago. ${ }^{26}$

Australia's nearest neighbour is the world's most populous Muslim-majority nation, Indonesia. The Muslim population of Indonesia approximates the Muslim population of the Arab League. Two Indonesian Muslim movements, Nahdlatul Ulama (NU) and Muhammadiyah, have claims to be the largest Muslim movements in the world, the first claiming to have between forty and sixty million adherents, the latter up to forty-five million. For most of the recent period, NU has had significant elements which have been positively inclined to Jews and a willingness to be open to discussion about Israel. Muhammadiyah has also contained elements which have worked to promote inter-religious understanding. Both have played essential roles in defining Indonesian identity-and have been conscious of the potential of Indonesian Muslims to impact Global Islam.

Over ten journeys to Indonesia and countless interactions with Muslim Indonesians in Australia, it has been interesting to observe a range of attitudes toward Jews. ${ }^{27}$ Most Indonesians have never met a Jewish person. For many of them, real, living Jews are of little interest. "Palestine" is an important social

24 Cf. Jones vs. Scully [2002] FCA 1080 (September 2, 2002, Judgement of Federal Court of Australia).

25 Cf. Executive Council of Australian Jewry Media Release, "One Nation's Publication of AntiJewish Material Declared Illegal," no date; Jeremy Jones, and on behalf of the Executive Council of Australian Jewry vs. The Bible Believers Church - [2007] FCA 55, February 2, 2007.

26 Council of Presidents of the Lutheran Church of Australia, Lutherans and the Jews, issued September 29, 1996, accessed March 30, 2020, http://www.jcrelations.net/Australian_Luther ans_A_statement_on_Lutherans_and_Jews.2380.0.html?L=6\%29\%2C $\% 29.05 \mathrm{C} \% 5 \mathrm{C} \% 5 \mathrm{C} \% 5 \mathrm{C} \%$ 5C $\% 5 \mathrm{C} \% 5 \mathrm{C} \% 27 \% 28 . . \% 2 \mathrm{C} \% 5 \mathrm{C} \% 5 \mathrm{C} \% 5 \mathrm{C} \% 5 \mathrm{C} \% 5 \mathrm{C} \% 5 \mathrm{C} \% 5 \mathrm{C} \% 27 \&$ page $=3 \& \mathrm{pdf}=1$.

27 Cf. “Jones Makes Interfaith History,” The Australian Jewish News, August 18, 2015, https://ajn. timesofisrael.com/jones-makes-interfaith-history/. 
cause, but understanding of the history and contemporary situation of Israel and Palestinians is generally superficial. ${ }^{28}$

Knowledge of Jews-as a concept rather than a segment of humanity-comes from a variety of sources. Many of my visits to Indonesia have been directed at Muslim centres of scholarship and social organisation, and the Qur'an is a primary informer of ideas about Jews. Various readings of the Qur'an permit positive, negative, or mixed views of Jews as monotheists gone astray through to deserved objects of contempt, with the historic burden for transmission of understanding falling upon religious teachers. Which hadiths are accepted, taught, and emphasised, which tafsir (exegesis) is given prominence and what is included in weekly khutbah (Friday "sermons") provide the religious overlay on understanding of how Indonesians feel they are meant to understand Jews.

Another source is the behaviour of role models. Former NU leader, and the first elected president of democratic Indonesia, Gus Dur (Abdurrahman Wahid) was, indisputably, a serious international proponent of not just dialogue but of good relations with Jews. His legacy lives on, in a far more significant way than that of Amien Rais, a former Muhammadiyah leader who was hostile beyond the call of duty. ${ }^{29}$

The new kid on the block is global communications media. In question and answer sessions on campuses, in pesantrans, and in NGO round-tables, there is one introduction to any question which can chill the spine-- "I have done a lot of reading on the internet..." Far be it from me to belittle the internet as a source for genuine information and thoughtful opinion, but this introductory comment seems to be invariably followed by base antisemitism, distortion of history or invented events. In Indonesia, critiques of Jews drawn from the internet are generally uncontradicted.

I have escorted numerous groups from majority Muslim countries through the Sydney Jewish Museum and this, together with the groups of Islamic leaders I have accompanied to dialogue meetings in Israel, has prompted my invitations to educate in Indonesia. ${ }^{30}$ But to do this with any level of effectiveness and credibility, it has been necessary for me to learn a great deal about Islam.

28 Cf. J. Hadler, "Translations of antisemitism: Jews, the Chinese and Violence in Colonial and Post Colonial Indonesia,” Indonesians and the Malay World 32, no. 94 (November 2004): 291313.

29 Cf. G. Barton, "Islam and Politics in the New Indonesia," in Islam in Asia: Changing Political Realities, ed. J. F. Isaacson and C. Rubenstein (London: Transaction, 2002), 37-38.

30 A report of one such visit can be found at "Indonesian Muslim Leaders promote dialogue in Israel and Palestinian Authority,” J-Wire, issued January 30, 2017, accessed March 30, 2020, 
If asked by an engaged Muslim if one has read the Qur'an, it is better than not to be able to answer in the affirmative. Familiarity with Islamic prayer, observances, cultural nuances, and more are, in my experience, essential for meaningful relationships and respect.

A Jewish person in much of the world is a novelty, a curiosity but not an unknown, due to religious texts, in the Muslim or Christian worlds. In my experience, there is a thirst for understanding how Jewish people live, what is believed by Jews, where Jews differ from each other and from Muslims and adherents of other faiths. It can be very difficult to begin the conversation, and it requires a great deal of work to develop the skills for constructive interactions, but if one is serious about combatting antisemitism, the effort is worthwhile.

Despite geography, the Australian and Indonesian circumstances are, objectively, worlds apart. But they are linked by both being subjected to major impacts by growing globalisation.

Australian education for multiculturalism is now in competition with online education for racist, national assertions of identity. Global connectivity has fractured a model of responsibility, engagement, and a localised social contract. It is not helpful that this coincides with a lack of respect for many traditional institutions.

Australian benchmarks for acceptable discourse are not respected in a globalised communication world. While laws assert acceptable discourse in any specific constituency, online environments have no such understandings, even where online activity is subject to domestic law.

Efforts by local religious leaders to live well in multi-identitied environments, which can be careful, nuanced, and sophisticated, can be undermined due to the ability of remote figures to engage and influence. This is a problem in Australia but a far greater problem in Indonesia.

\section{So What Can Be Done?}

First, we need to rethink our strategies and priorities. We can no longer think globally and act locally and think that will be good enough. We can not abandon local action, but we must recognise the changed contexts in which we operate.

https://www.jwire.com.au/indonesian-muslim-leaders-promote-dialogue-in-israel-and-pales tinian-authority/. 
The internet and associated social media is global. It is international. Informational battles need to be engaged on many fronts, and it does not matter where a person addressing disinformation is based. The issue is sorting out priorities and maximising human and other resources.

Christianity is global. There are identifiable hubs of supersessionism and other forms of antisemitism. We need to address local, national, and regional churches but also work with them to fight evil internationally.

A Eurocentrism in the fight against antisemitism may lead to the conclusion that there are not many Jewish people who have had engagements with Islam similar or greater than Jewish Europeans have had with Christianity. But there are Jews who have lived in Islamic societies and others who have taken the time and made the effort to learn about Muslims and Islam and are equipped to engage and help break down misconceptions. That said, we need more people, Jewish and otherwise, who can and will devote themselves to work in this area.

Perhaps, as a first stage, we need to map the universe of anti-antisemitism: Who and where, how and how successfully. We also need to identify role models, inspirational figures, with standing and/or celebrity.

It is possible that the time when "Non-antisemitism" will be proclaimed by antisemites may pass-and sooner rather than later. Whether we progress to genuine absence of antisemitism or a tsunami of overt antisemitism to no small degree depends on our skills in understanding the challenges and effecting intelligent strategies.

Jeremy Jones AM is an Australian writer, public speaker, human rights advocate, and interfaith activist. He is widely published on contemporary antisemitism and relations between world religions and has lectured on these subjects in more than thirty countries. He is Director of International and of Community Affairs for the Australia/Israel \& Jewish Affairs Council and an Honorary Life Member and Former President of the Executive Council of Australian Jewry.

\section{References}

Aldeeb Abu-Sahlieh, Sami A. The Fatiha and the Culture of Hate: Interpretation of the 7th Verse through the Centuries. Scotts Valley: Create Space, 2015.

Barton, Greg. "Islam and Politics in the New Indonesia." In Islam in Asia: Changing Political Realities, edited by Jason F. Isaacson and Colin Rubenstein, 1-90. London: Transaction, 2002.

Council of Presidents of the Lutheran Church of Australia. Lutherans and the Jews. Issued September 29, 1996. Accessed March 30, 2020. http://www.jcrelations.net/Australian_Lu 
therans_A_statement_on_Lutherans_and_Jews.2380.0.html?L $=6 \% 29 \% 2 \mathrm{C} \% 29 . \% 5 \mathrm{C} \% 5 \mathrm{C}$ \%5C \%5C\%5C\%5C\%5C\%27\%28...\%2C\%5C\%5C\%5C\%5C\%5C\%5C\%5C\%27\&page=3\&pdf=1. Glick, Caroline B. “Column One: Hamas and the Nexus of Global Jihad." The Jerusalem Post, February 5, 2015. https://www.jpost.com/Opinion/Hamas-and-the-nexus-of-global-jihad390182.

Guerrero, Eszter Susan, and Adam Schonberger. "The Nationalist Hungarian Government is Endangering Jewish People with its Smear Campaign against Philanthropist George Sorors." The Independent, December 3, 2017. https://www.independent.co.uk/voices/ hungary-government-george-soros-viktor-orban-antisemitism-a8089621.html.

Hadler, Jeffrey. "Translations of antisemitism: Jews, the Chinese and Violence in Colonial and Post Colonial Indonesia." Indonesians and the Malay World 32, no. 94 (November 2004): 291-313.

Haverluck, Michael F. "Muslim Refugees' Archaic Views of Jews, Women, Infidels.” One News Now, January 23, 2018. https://onenewsnow.com/culture/2018/01/23/muslim-refugeesarchaic-views-of-jews-women-infidels.

Hirsh, David. Contemporary Left Antisemitism. London: Routledge, 2018.

Irving, David. “Action Report." Issued July 20, 2000.

Pope John Paul II. "To the Representatives of the Jewish Community in Sydney." Speech. Issued November 26, 1986. Accessed March 30, 2020. http://www.vatican.va/content/ john-paul-ii/en/speeches/1986/november/documents/hf_jp-ii_spe_19861126_com-ebra ica-sidney-australia.html.

Pope John Paul II. "To the Jewish Community of Rome." Speech at Rome Synagogue. Issued April 13, 1986. Accessed March 30, 2020. http://www.vatican.va/content/john-paul-ii/ de/speeches/1986/april/documents/hf_jp-ii_spe_19860413_sinagoga-roma.html. [German]

Jones, Jeremy. "Confronting Reality: Anti-Semitism in Australia Today." Jewish Political Studies Review 16, nos. $3-4$ (2004). https://www.jcpa.org/phas/phas-jones-f04.htm.

Jones, Jeremy. "Durban Daze: When Anti-Semitism becomes Anti-Racism." Australia/Israel Review, October 26, 2001.

Jones, Jeremy. "Erasing Hatred.” Australia/Israel Review. July 25, 1997.

Jones, Jeremy. "The Jewish Community of Australia and Its Challenges." Jerusalem Center for Public Affairs 13 (2006). https://jcpa.org/article/the-jewish-community-of-australia-andits-challenges/.

Marchant, Robert. "We Need to Talk about Momentum and anti-Semitism." Labour Uncut. Issued January 17, 2018. Accessed March 23, 2020. http://labour-uncut.co.uk/2018/01/ 17/we-need-to-talk-about-momentum-and-anti-semitism/.

Marcus, Kenneth L. "Is the Boycott, Divestment, and Sanctions Movement Anti-Semitic?" In The Case Against Academic Boycotts of Israel, edited by Cary Nelson and Gabriel N. Braham, 243-58. Chicago: Wayne State University Press, 2015.

MEMRI, Special Dispatch No.7025. "Egyptian Writers Criticize The Negative Attitude to Christians and Jews Reflected in The Common Interpretation of the Fatiha." Issued July 25, 2017. Accessed March 23, 2020. https://www.memri.org/reports/egyptian-writerscriticize-negative-attitude-christians-and-jews-reflected-common.

N. N. "Indonesian Muslim Leaders promote dialogue in Israel and Palestinian Authority." J-Wire. Issued January 30, 2017. Accessed March 30, 2020. https://www.jwire.com.au/in donesian-muslim-leaders-promote-dialogue-in-israel-and-palestinian-authority/. 
N. N. “Jones Makes Interfaith History.” The Australian Jewish News, August 18, 2015. https:// ajn.timesofisrael.com/jones-makes-interfaith-history/.

N. N. "Norwegian MP Defends Nominating 'Peaceful' BDS Movement for Nobel Prize." The Times of Israel, February 11, 2017. https://www.timesofisrael.com/norwegian-mp-de fends-nominating-peaceful-bds-movement-for-nobel-prize/.

Nicholls, William. Christian Antisemitism: A History of Hate. London: Jason Aronson, 1993. Pope Paul VI. Nostra Aetate: Declaration On The Relation Of The Church To Non-Christian Religions. Issued October 28, 1965. Accessed July 17, 2018. http://www.vatican.va/ar chive/hist_councils/ii_vatican_council/documents/vat-li_decl_19651028_nostra-aetate_ en.html.

Rich, Dave. The Left's Jewish Problem. London: Biteback, 2018.

Rutland, Suzanne. "Negotiating Religious Dialogue: A Response to the Recent Increase in anti-Semitism in Australia." In Negotiating the Sacred: Blasphemy and Sacrilege in a Multicultural Society, edited by Elizabeth Burns Coleman and Kevin White, 17-30. Canberra: ANU Press, 2006.

Sugarman, Daniel. "A Short Guide to Neturei Karta, the anti-Zionist's Favourite Fringe Jewish Sect.” The Jewish Chronicle (UK), September 11, 2017, https://www.thejc.com/comment/ comment/who-are-the-neturei-karta-1.444090.

World Jewish Congress, ed. My Brother's Keeper: World Conference on Anti-Semitism and Prejudice in a Changing World, July 6-8, 1992, Brussels, Belgium. Brussels: World Jewish Congress, 1992. 